\title{
On Parody
}

Images

vol. XIV/no. 23

Poznań 2014

ISSN 1731-450x

A true story: I have a student who emails me and says he cannot meet me for tutorial at the 1:00 p.m. time upon which we had agreed. Instead, he says, "I can only meet you at 1:05 p.m." This strikes me as rather too specific, intimating obsession. It is also funny. Pushing the exactness of times beyond the realm of reasonableness, I write back: "I cannot meet you at 1:05p.m., but 1:07p.m. is available; please confirm". When he shows up at my office-at 1:07p.m.-we both laugh. He understands parody given without malice. In this instance, parody also leads to a mutual confession of obsessive-compulsive behavior, and a therapeutic moment between student and teacher. The tone of parody is not always so benign, or mutually implicating.

Frederick Crews, a well-known American literary scholar, famous for having turned against the Freudian psycho-analytic method he had earlier used in discussing Hawthorne and other authors, wrote a very funny and pointed set of two books that parody most of the fashionable methods of analysis in the humanities: The Pooh Perplex: A Student Casebook (1964) and Postmodern Pooh (2001). The parody-with-a-point starts with the titles: poor Pooh, the endearing bear of A.A. Milne's beloved childhood books, is to be put under the feigned scrutiny of humorless adult scholars, whose methods of analysis have lost their sense of decency. In the process, Crews also parodies the standard genre of student "casebooks" for academic topics. The fun continues unabated inside, with titles such as: "A.A. Milne's Honey-Balloon-Pit-Gun-Tail-Bathtubcomplex", authored by Karl Anschauung, M.D., and "The Fissured Subtext: Historical Problematics, the Absolute Cause, Transcoded Contradictions, and Late-Capitalist Metanarrative (in Pooh)", by Carla Gulag. Even the "grammar" of the titles of scholarly conference titles and essays, with their endless colons and semi-colons, is being sent up, and not always without malice. Crews' patience is wearing thin with his own past, and with his colleagues' race to smother the pleasures of reading with theory that has escaped any sense of proper boundaries. There is therapy in Crews' parody, as well, especially for other academics who might also be sinking under the seemingly endless and manic march of hermeneutic methods over one another and over texts of all kinds. One could also parody Crews: How We Made it Through the Dark Nights of the Scholars' Soul with Crews' Casebooks: A Guidebook for Unhinged Academics-or, perhaps more simply, Crews' Casebooks: A Guidebook for Students (forthcoming). The amusement decreases with the meta-parodies.

Five Examples, with Statements 
Ingmar Bergman's film Persona (1966) contains a plot that takes us to another notion of parody, one well described by the notions of mask, masking, and persona. A nurse is put in care of an actress, and they are then sent to an isolated cabin for "therapy" by a psychiatrist. We learn that the nurse is identified with her personae of nurse, loyal fiancé, and future wife and mother-all sweetness and light. We learn that the actress is pretending to be a good mother and wife. But something has rendered her silent. When the actress betrays the nurse's confidence, a dark and violent side of the nurse erupts and shatters the brittle pretense of a personality made only of sweetness and light. When the nurse penetrates the actress's dark secrets, a mutual double unmasking occurs. Here parody has something to do with willfully pretending-or unconsciously acting as if incomplete persona-presentation is all that one is. When this lack of self-knowledge becomes evident, the mask is experienced as a parody of a more complete personality. This experience can be shattering; it so for the nurse, who apparently retreats from this self-knowledge. The actress apparently returns to the stage, with results not made clear in the film. The therapeutic results are very much in question at the film's end.

The faux-documentary is a doubly rich arena for parody. First, it plays with the truth-function upon which the documentary genre's credibility rests. Second, it characteristically parodies the putative subject being portrayed. A Polish master of the faux-documentary, Marek Piwowski, sends up the Polish military's performance anxiety" about having the right military step prior to the country's entry into NATO in Krok (1997). In the process, he uses wacky reduction ad absurdum as a therapeutic mirror for his viewers. His earlier cult film, Rejs (1970) is a treasure trove of sharply pointed, but somewhat coded, parodies of behavior in the communist 196os. The behavioral and cultural references in many of the tableaux necessarily escape non-Polish viewers, but enough comes through, especially the dead-pan tone, to make the film an hilarious experience of parody for us as well.

Jokes of all kinds are ripe sources of parody. Two short communist-era jokes with many versions runs thus: (1) "What is the difference between capitalism and communism? In capitalism, man exploits man. In communism, it's the other way round." (2) "Peaceful coexistence: A Soviet and an American were arguing over which of their cars was the faster, and finally decided to settle the matter by a race. The American car proved to be faster. Next day, the event was reported in Pravda, as follows: At an international rally, the Soviet car placed second. The American car finished next to last." Such jokes serve as a survival strategy by parodying ideological cant and puffery. Polish cabaret during the communist period also served this function.

Eleven Statements, with Examples
1. Parody is a second-order discourse; sometimes parasitic, but not always. The parasitic function is a matter of intent and tone. Sometimes those who parody are accused of being "social parasites" by those whom they have targeted. This is a dangerous place to find oneself. 
Non-parasitic parody causes the thing parodied no harm, in the several senses of the word: energetic, psychological, ideological, and so on. Parody is a form of ironic mimicry. It's "originality" is always derivative, and therefore ironic.

2. Parody is not analogy. Parody is not metaphor. Parody is not synecdoche. Nor is parody a facsimile of the original text. From an exact copy, one can reproduce the thing copied, because of the mirror-symmetry that exists between them. On occasion, one can at least reconstruct some semblance of the original from the parody; for example, one can move with accuracy from Andy Warhol's soup-can paintings to the original objects with a fair measure of assurance. One can also move from a Marilyn Monroe or Elvis Presley look-alike to the original; ironically, the look-alike who identifies with Monroe or Presley may not be aware that s/he is a parody of Monroe or Presley.

3. Some parody will not be recognized as parody, for lack of a known referent: for example, because the text parodied is unknown or has disappeared in time. Do we know what Cervantes' Don Quixote (1605/1615) parodies? How would we proceed to ascertain parody in such cases? The descriptions of indigenous culture by foreign conquerors raise such questions. The statement that "history belongs to the victors" points to the same issue. The victor and conquerer may or may not be aware that the history they have written is a parody of truth. Parody-as-history has a long history.

4. Parody is susceptible over time to parody, but the pay-off is sharply decreased, because a derivative of a derivative easily becomes tiresome. Acquaintance with a person over time may lead one to believe that this person is a self-parody. A person can get lost in self-parody, even if it is expressed ironically. One value of friendship is the friend's capacity to recognize this fact and express it.

5. Parody can embody various tones, including competitiveness, sarcasm, sympathy, false sympathy, envy, disgust, humor, and a therapeutic impulse. Parody can also feign such tones: for example, "playful" sarcasm.

6. Parody in the wrong time or place can be dangerous: for example, a four-eyed Stalin (Skolimowski's Ręce do góry, 1967/1985). Correct timing may be crucial: Wajda's parody of socialist realism in Man of Marble (1977).

7. Because of their ontological differences, verbal, visual, and musical art express parody by different means. However, they can express parodies of one another in restricted ways: for example, visual or musical parodies of uses of language.

8. The apparently inherent urge of social engineering in both capitalist and communist societies, to place persons in functionally defined slots disregards the person's fuller humanity. Such social organizations are therefore themselves parodies, and their images of humankind are parodies. An aesthetic form of such dual parodies is socialist realism. Mass culture fosters such parodies in celebrity-hood, 
celebrity cults, and some forms of utopianism. Perfectionism in social roles is an insidious form of parody, because it is rewarded by money and given honorific status. Social engineers are sometimes not aware that they are creating parodies of humanity. This may happen because they sincerely self-identify with the parody they are creating. When they are aware that they are creating a parody of humanity, they typically cynically hide the ruse because they seek to remain in power.

9. Such ruses are favorite targets of artists who are combating the corruption of consciousness. The artist may use parody to attack such parodies. Wajda's parody of socialist realism is again one example. American middle class manners and culture, which themselves embodied a parody of the full spectrum of human possibilities, were an easy target for Mack Sennett's slapstick comedies in the early period of American silent film. And Charlie Chaplin's The Great Dictator (1940) parodied the inflationary insanity of totalitarian social engineering. Parodies in this vein perform one of art's most important functions.

10. Some parody targets a text: Ingmar Bergman's The Seventh Seal (I957) has been a favorite target for young filmmakers. Some parody targets an artistic genre or a definition of art: faux-documentary and Marcel Duchamp's Fountain (1917). Some parody targets a reductive image of humanity. Some parody targets self-deception: for example, in psychotherapeutic interventions where the therapist mimics the client-or vice versa. Some parody targets itself. There remains the interesting question: is everything open to parody? Some things seem more susceptible to parody than others, but perhaps we have not reached the boundaries of parody.

11. Essays on parody characteristically take themselves too seriously, even though they might be unwitting parodies of coherent thought. Thus might they stumble on the banana peel of their own self-deception. Whatever banana peels hide inside this essay belong to the author. 